\title{
Teaching-Learning Strategies to Production Planning and Control Concepts: Application of Scenarios to Sequencing Production with Virtual Reality Support
}

\author{
Fernando Elemar Vicente dos Anjos \\ Instituto Federal de Educação, Ciência e Tecnologia do Rio Grande do Sul \\ (IFRS), Campus Caxias do Sul. Caxias do Sul, Brazil; and \\ UNISINOS -University of Vale do Rio dos Sinos \\ https:/ / orcid.org/0000-0002-9096-2806 \\ Luiz Alberto Oliveira Rocha \\ UNISINOS - University of Vale do Rio dos Sinos, São Leopoldo, Brazil \\ https://orcid.org/0000-0003-2409-3152 \\ Rodrigo Pacheco \\ Instituto Federal de Educação, Ciência e Tecnologia do Rio Grande do Sul \\ (IFRS), Campus Caxias do Sul, Caxias do Sul, Brazil \\ https://orcid.org/0000-0002-9399-4475 \\ Débora Oliveira da Silva \\ UNISINOS - University of Vale do Rio dos Sinos, São Leopoldo, Brazil \\ https://orcid.org/0000-0001-7023-4927
}

\begin{abstract}
This paper aims to present scenarios to be applied in higher education to the theme of production planning and control, addressing factors of the production system and indicators arising from this process and the application of virtual reality to support the process. The applied method combines the development of six scenarios for virtual reality application and the discussion about the impacts in indicators from the production planning and control, for example, inventory in the process, manufacturing lead-time, use of equipment, and punctual delivery attendance. Findings revealed that the teaching-learning process of production planning and control, when applied through scenarios, generates opportunities for students to learn the impact in the indicators. The virtual reality in this environment supports creating differentiated teaching-learning environments to generate the most significant knowledge for students which positively impacts the future in the world of work. In addition, it allows people involved in the teaching-learning processes of production engineering to apply the
\end{abstract}


concepts presented in the sequencing process, lean about the impacts of decisions on production sequencing indicators and appreciate the support of virtual reality to generate an environment more cognitive for students.

Keywords: teaching-learning in production engineering; engineering dducation; planning and production control; virtual reality in teachinglearning process; production sequencing

\section{Introduction}

When teaching-learning strategies are approached, several paths can be traced. Mizukami (1992) presented five teaching approaches: traditional, behavioural, humanistic, cognitive, and socio-cultural. Santos (2006) highlighted that cognitivism proposes that knowledge is generated through experiments in the world, analyzing aspects through intervention in the processes, rescuing the discussion on theoretical studies of cognitive psychology presented by Piaget and Vigotsky. They explained the theory of learning called constructivism.

In 2019, the ASEE Annual Conference \& Exposition (promoted by the American Society for Engineering Education) took place, in which a conference proceeding was published that presented a discussion of cognitive teaching approaches to Engineering. In this discussion, Crawley et al. (2019) described that the new MIT program, called New Engineering Education Transformation (NEET), brings information that alumni are better prepared to work as innovators, creators, entrepreneurs, and future leaders, when knowledge is developed through cognitive approaches, for the formation of critical, systemic and humanistic thinking. They also supported professionals to learn and think more effectively on their initiative throughout their lives.

The creation of environments that seek to prioritize cognition can be organized and explored in different ways. Prensky (2001) highlighted the importance of applying technologies in the teaching-learning process, and Wang et al. (2017) pointed out in their research that the application of technologies can positively impact students' learning. Some researches present the application of mobile technology, virtual reality, and augmented reality as part of the teachinglearning strategies in cognitive environments. Examples of such uses are the investigation of crime scenes (Mayne \& Green, 2020), the teaching of chemistry (Frevert \& Di Fuccia, 2019), functional spectroscopy (Lamb et al., 2018), and medical surgery (Żechowicz et al., 2018), among others. Positive cases of the application of virtual reality and augmented reality in the learning and satisfaction of students can be perceived in research in several areas of engineering, such as, , data structuring (Akbulut et al., 2018), machining manufacturing processes, and robotics (Grodotzki et al., 2018), along with construction of buildings and construction environments and equipment (Sánchez et al., 2015; Shirazi \& Behzadan, 2015).

Anjos et al. (2020) described in their research that there are some applications of virtual reality in the teaching-learning processes of production engineering, and 
there are many other opportunities for the application of virtual reality that measure the results in the teaching-learning process or also measure the satisfaction of students when using such a method. Thus, they indicated future research in production systems management, production planning, control, material handling, production simulation, production process management, metrological quality organization, work organization, accident risk analysis and prevention, work safety, process, and product ergonomics.

Through the perception of the importance of teaching-learning environments with cognitive bias in the training of students and impacts on their professional career and the application of technologies in the formation of the cognitive environment and the opportunities for new research with the application of virtual reality highlighted by Anjos et al. (2020), the following research questions arise:

1- What concepts of production planning and control could be developed in virtual reality?

2- Which theoretical bases applied to the virtual reality model should be taken into account?

3- What are the model's requirements, and why would it strengthen the studied concepts?

The general objective of this study is to develop a virtual reality application model with different scenarios, to be used as a teaching-learning strategy for production planning and control concepts.

This research is justified because applying virtual reality models, in some cases, increases the level of knowledge retention of the subjects studied, such as from $25 \%$ to $80 \%$ after three weeks of studies carried out with virtual reality, when compared to students who used only the traditional teaching method (Laseinde et al., 2016). Students learn more using virtual reality than students who only took classes with the traditional teaching method (Inayat et al., 2016) and were more satisfied and engaged with the subjects studied (Fonseca et al., 2016). The more increase in knowledge retention, the highest level of learning, satisfaction, and engagement positively impact organizations because professionals entering the job market arrive entirely with more acquired knowledge, supporting organizations and making them more competitive in the market than its competitors (Anjos et al., 2020).This article is organized in the following sections: the theoretical framework, methods, results, analysis of results, and conclusion, along with some limitations and future research suggestions.

\section{Theoretical Background}

\subsection{Cognitive Environments}

According to Lefrançois (2016), expectations that drive behaviour are formed by cognitions, and are developed after experiences with styles and rewards. This strategy is a way for teachers to stimulate students through their expectations and learning objectives formed in a cognitive environment. It is also highlighted that an essential part of the cognitive environment is related to the perception (generated by significant experiences) of the formation of concepts, memories, 
languages, thinking, problem-solving, and decision making. In the same line of thought, Kanakana-Katumba and Maladzhi (2019) described that the cognitive teaching-learning environment must take into account some characteristics, such as (I) interrogative approach, (II) experimental learning, (III) problem-based learning, (IV) case-based learning, (V) project-based learning, (VI) researchbased learning, and (VII) competency-based learning.

According to Mestrinho and Cavadas (2018), the interrogative approach is innovative in higher education environments and becomes a good practice for introducing the collaborative approach and bringing energy to the teachinglearning environment. Bates (2015) claimed that the experimental approach is widely used in engineering, allowing students to practice the concepts and theories developed. The problem-based methodology has the characteristic of organizing students into groups to deal with previously defined problems as well as presenting solutions through studied concepts (Bates, 2015; Tsai et al., 2015).

Case-based learning uses extensive discussion in the teaching-learning processes by discussing cases and examples of possible solutions (Bates, 2015). Projectbased learning is similar to case-based learning. However, according to Bates (2015) and Mestrinho and Cavadas (2018), the scope of the work is broader and presents real challenges and tasks that often generate manual work and not theorists only. Research-based learning is similar to project-based learning, yet the instructors control the situation in the learning environment (Hwang et al., 2015; Soudien, 2010). Finally, competency learning allows students depending on their level of knowledge to learn more quickly. This approach allows one to demonstrate competence and permits students to control their learning (Bates, 2015; Kreamer et al., 2015). Quadir et al. (2019) highlighted a positive existence of cognitive learning environments if interactive activities with feedback and multimedia components are used compared to subjective and objective learning of students.

\subsection{Virtual Reality and Cognitive Environments}

Virtual reality can create artificial environments that can be used for different purposes. According to Lamb et al. (2018), virtual reality environments happen through the interaction between man and machine, as there is a simulation of a real environment that can create interaction and communication between them. Martins and Guimarães (2012) described that these environments use multisensory technology that uses elements of computer graphics to create virtual environments. They also highlighted that these environments have characteristics related to immersion, interaction, and involvement, which work according to the relationship between the user and the virtual environment. Such characteristics are shown in Table 1. 
Table 1. Basic characteristics related to the virtual world

\begin{tabular}{|l|c|}
\hline Immersion & $\begin{array}{c}\text { No } \\
\text { immersionwhenthecomputationallydevelopedenvironmentisviewedthr } \\
\text { ough a desktop screenorprojectedvisualization. }\end{array}$ \\
\cline { 2 - 3 } & $\begin{array}{c}\text { Withimmersion, whentheuserfeelstotallyinside a } \\
\text { computationalenvironment, usuallyusingvisualizationglassesorCAVEs } \\
\text { (Cave Automatic Virtual Environment). }\end{array}$ \\
\hline Interaction & $\begin{array}{c}\text { No interactionwhentheuser does notinteractwiththe virtual } \\
\text { environment. }\end{array}$ \\
\cline { 2 - 3 } & $\begin{array}{c}\text { Withinteraction, whenconnectedtothecomputer'sabilitytodetectuser } \\
\text { input andinstantlymodifythe virtual world and its actions. }\end{array}$ \\
\hline Involvement & $\begin{array}{c}\text { It isrelatedtotheconditionofthelevelofinvolvementof a userwith a } \\
\text { givenaction, whichcanbe passive, such as, receiving training, } \\
\text { viewingthe virtual environment, oractive, such as reading a book, } \\
\text { participating in virtual surgery. }\end{array}$ \\
\hline
\end{tabular}

Adapted from Martins and Guimarães (2012).

Schlemmer and Backes (2015) emphasized that virtual reality applications bring a very realistic environment involving the participants. When applied in the teaching-learning processes, this possibility allows students to enjoy presence, immersion, interaction, and involvement, which are all combined in enhancing the learning results. In the same vein, Duncan et al. (2012) described all the benefits of the virtual environment in the teaching-learning processes, merely in the option of formative laboratory, collaborative work, socialization, and entertainment. Gilbert (2004) explained that science subjects can be abstract, and therefore, for deep learning, the virtual world is a valuable tool. Smutny et al. (2019) highlighted that, in higher education, the application of virtual reality in curricula positively impacts student engagement and motivation to learn.

\subsection{Virtual Reality in the Teaching-Learning Processes of Production Planning and Control}

Production engineering is an extensive area. In some regions of the world, it is even called industrial engineering or management engineering. In Brazil, the guidelines for this area are organized by the Brazilian Association of Production Engineering - ABEPRO. The ABEPRO (2008) described the curricular guidelines to be applied in production engineering, organizing them in: I) Production Management; II) Quality Management; III) Economic Management; IV) Ergonomics and Workplace Safety; V) Product Management; VI) Operational Research; VII) Strategic and Organizational Management; VIII) Organizational Knowledge Management; IX) Environmental Management; and X) Education in Production Engineering. As a sub-topic of item I, the theme of production planning and control is in the same document. This theme is fundamental for organizations because it is responsible for processing all sales information and future demands and generating information on production needs for the productive, supply, logistics, and purchasing departments. (Lage Junior, 2019).

The production planning and control process has another extremely relevant function. Through the information generated for all subsystems of the organization, deliveries are generated to customers within the agreed terms at a 
reasonable cost (Corrêa et al., 2019). The production scheduling technique impacts the use of equipment idleness and delays in scheduled deliveries (Habib et al., 2015). Some factors need to be considered to execute production sequencing, namely rules and guidelines of the productive system and performance indicators (Corrêa et al., 2019). Among the rules and guidelines for sequencing production, some researchers highlight relevant factors in production planning and control, such as, fixed production batches or dynamic production batches (Brahimi et al., 2017; Suzanne et al., 2020), organization of production systems for discrete, continuous or project production (Armbruster et al., 2012; La Marca et al., 2010), equipment failure rate (Göttlich \& Knapp, 2019), setup times and manufacturing lead time (Allahverdi \& Soroush, 2008), processing time and Take time (Ayough et al., 2020), production capacity available for the execution of the planned production (Babaei et al., 2014; Oliveira \& Costa, 2018), organization of the layout, according to the processing and material flow scripts (Caicedo et al., 2019).

When evaluating the performance indicators of a production system, the results of decisions of the production sequencing impact in the indicators, for example, delivery attendant, delay of order, production advance, production lead time, number of overdue orders, inventory in the process, and use of equipment (Lustosa et al., 2008).

\section{Method}

The method applied to this research is organized in six stages as described in Figure 1.

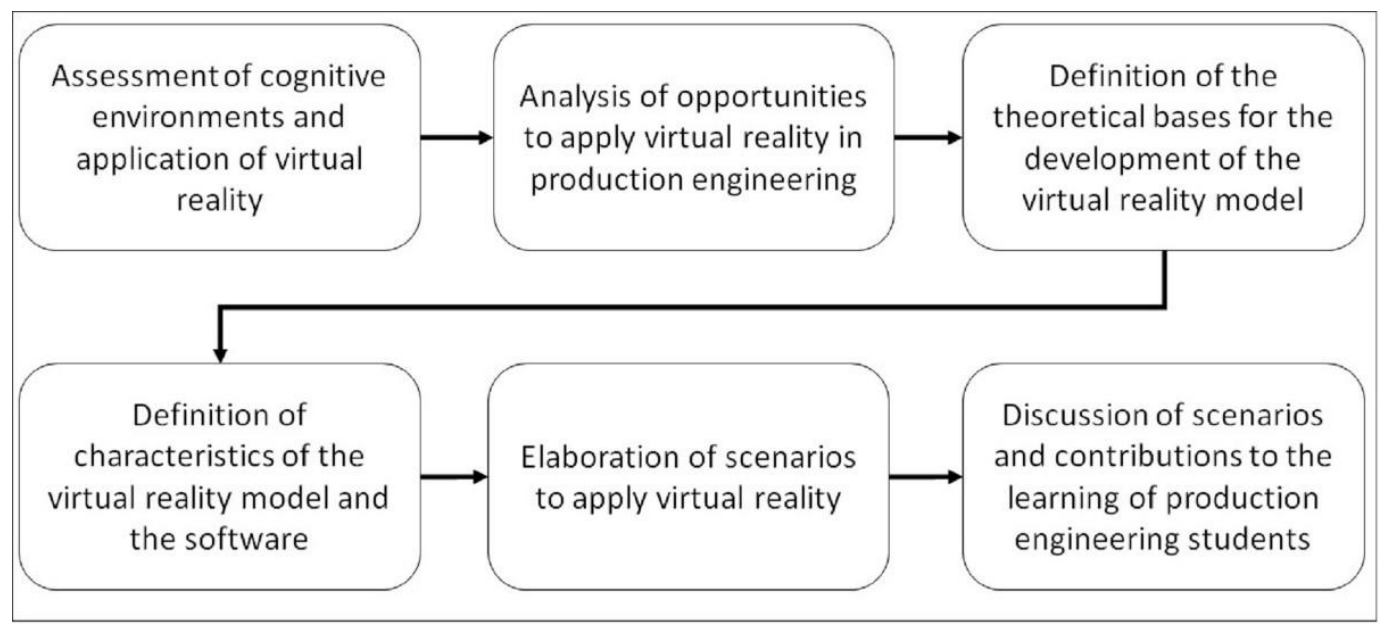

Figure 1. Method applied in the research

As displayed, steps 1,2, and 3 of the method are described in the introduction sections and the theoretical background on the developed theme. Stage 4 of the method was segregated into two stages: defining the model's characteristics and which software to use.

The virtual reality model used has a combination of factors that influence decisions about production sequencing, which will be organized in scenario formats to collect different results and how each factor impacts the results from 
the production sequencing process. Each scenario was a mix of these guidelines: the size of production lots, equipment failure rate (MTFB and MTTR), setup times, processing times, production capacity, and demand. The scripts for the processing of materials and the layout did not vary between scenarios. The transfer batches will be identical to the production batches of scenarios 1 to 4 . The remaining scenarios will be informed in table 7 and 8 in the results section. The evaluated indicators are: inventory in the process, punctual delivery, manufacturing lead-time, and use of equipment.

The layout is organized in line. It consisted of six material processing equipment, six assembly departments, and a shipping department. With this equipment, eight different components will be processed. The processing equipment, assembly departments, and the materials that are processed are shown in Table 2.

Table 2. Equipment, assembly departments and parts processed in the scenarios elaborated

\begin{tabular}{ccc}
\hline MachinesandEquipment & Assembly Department & Processedparts \\
\hline Eq1 & MTG1 & Xa \\
\hline Eq2 & MTG2 & Xb \\
\hline Eq3 & MTG3 & Xc \\
\hline Eq4 & MTG4 & Xd \\
\hline Eq5 & MTG5 & Xe \\
\hline Eq6 & MTG6 & Xf \\
\hline-- & -- & $X \mathrm{~g}$ \\
\hline-- & -- & $X h$ \\
\hline
\end{tabular}

The organization of the equipment layout and the material processing flow are described in Figure 2.

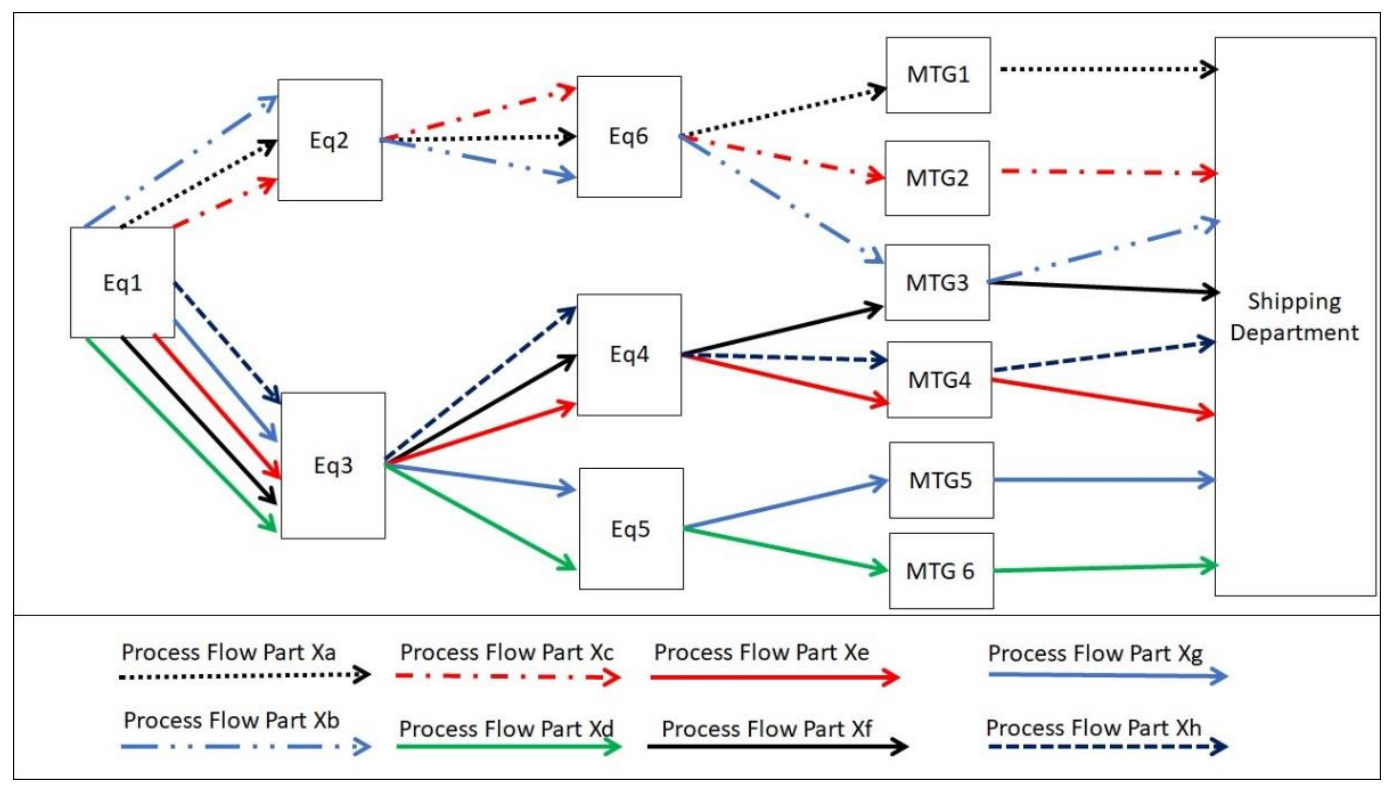

Figure 2. Layout of the production environment and material flow 
For executing the scenarios, the Siemens Tecnomatix Real NC® (2020) - Plant Simulation software will be used. The decision was made because this software can simulate dynamic and productive environments in virtual reality. The characteristic of virtual reality can be observed through the desktop, or its images can be transferred to viewing glasses with characteristics of immersion in the virtual environment. An example of the images generated in virtual reality by the chosen software is shown in Figure 3.

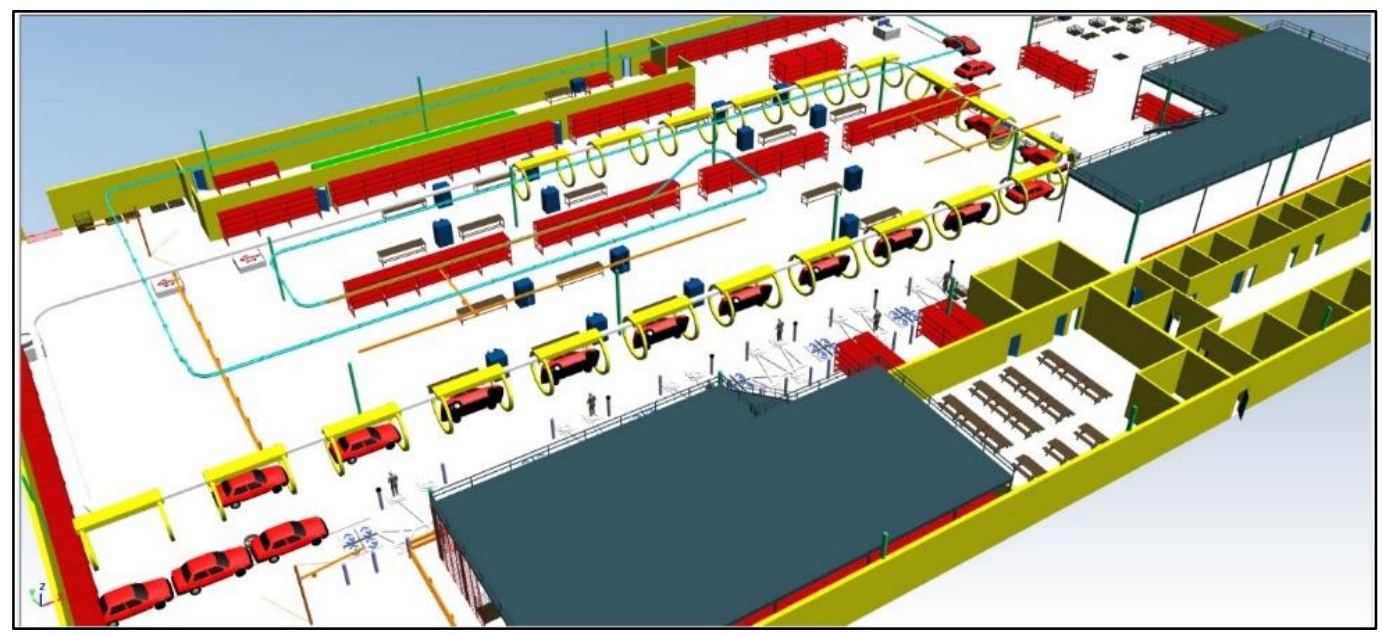

Figure 3. Example of virtual reality application with (Siemens Tecnomatix RealNC, 2020) - Plant Simulation

Source: http://www.engusa.com/pt_br/product/siemens-tecnomatix-plant-simulation

Proposals on the scenarios used to organize production planning and control are presented in the results section.

\section{Results}

As described in the method, it was necessary to organize a mix of guidelines that impact the production planning and control process results for the preparation of the scenarios. During the creation of Scenario 1, it was defined that the available capacity of the processing equipment would be 24 hours a day and that the manufacturing batches would correspond to seven days of demand from the assembly departments. The other information applied to this scenario is available in Table 3. 
Table 3. Scenario 1 for the application of virtual reality in the teaching processes of production planning and control

\begin{tabular}{|c|c|c|c|c|c|c|c|c|c|c|c|c|c|c|}
\hline & \multicolumn{6}{|c|}{ Processing times (seconds) } & \multicolumn{6}{|c|}{ Changeover times (seconds) } & \multirow{2}{*}{$\begin{array}{c}\text { Daily } \\
\text { Demand }\end{array}$} & \multirow{2}{*}{ Batch size } \\
\hline & Eq1 & $\mathrm{Eq} 2$ & $\mathrm{Eq} 3$ & Eq4 & Eq5 & Eq6 & Eq1 & $\mathrm{Eq} 2$ & $\mathrm{Eq} 3$ & Eq4 & Eq5 & Eq6 & & \\
\hline $\mathrm{Xa}$ & 25 & 35 & NA & NA & NA & 50 & 2400 & 3600 & NA & NA & NA & 2400 & 500 & 3500 \\
\hline $\mathrm{xb}$ & 30 & 30 & NA & NA & NA & 35 & 2800 & 3200 & NA & NA & NA & 2800 & 450 & 3150 \\
\hline$X_{C}$ & 25 & 28 & NA & NA & NA & 22 & 3200 & 4200 & NA & NA & NA & 3200 & 480 & 3360 \\
\hline $\mathrm{xd}$ & 18 & NA & 20 & NA & 20 & NA & 2750 & NA & 2800 & NA & 3600 & NA & 625 & 4375 \\
\hline $\mathrm{Xe}$ & 14 & NA & 25 & 41 & NA & NA & 3500 & NA & 3200 & 3500 & NA & NA & 312 & 2184 \\
\hline$x f$ & 25 & NA & 26 & 28 & NA & NA & 2400 & NA & 3600 & 2400 & NA & NA & 220 & 1540 \\
\hline $\mathrm{Xg}$ & 20 & NA & 21 & NA & 36 & NA & 2680 & NA & 4000 & NA & 2200 & NA & 200 & 1400 \\
\hline $\mathrm{Xh}$ & 15 & NA & 32 & 32 & NA & NA & 2700 & NA & 2400 & 2700 & NA & NA & 400 & 2800 \\
\hline $\begin{array}{l}\text { Failure Rate } \\
\text { MTTR + MTBF }\end{array}$ & $4 \%$ & $11 \%$ & $6 \%$ & $12 \%$ & $9 \%$ & $14 \%$ & \multicolumn{8}{|c|}{ Capacity available 24 hours a day } \\
\hline
\end{tabular}

The objective of this scenario is to demonstrate the impact of large manufacturing batches and high setup times on production sequencing indicators. With this scenario, lead time indicators, inventory in processes, and punctuality of deliveries (for the assemblies) will suffer impacts due to the production lot and setup times.

The second scenario was elaborated from the data used in Scenario 1. The same demand, capacity, cycle times, and failure rate data described in Scenario 1 were used. The manufacturing batches were changed to four days of demand and the setup times with an average reduction of $30 \%$. The data for Scenario 2 are revealed in Table 4.

Table 4. Scenario 2 for the application of virtual reality in production planning and control teaching processes

\begin{tabular}{|c|c|c|c|c|c|c|c|c|c|c|c|c|c|c|}
\hline & \multicolumn{6}{|c|}{ Processing times (seconds) } & \multicolumn{6}{|c|}{ Changeover times (seconds) } & \multirow{2}{*}{$\begin{array}{c}\text { Daily } \\
\text { Demand }\end{array}$} & \multirow{2}{*}{ Batch size } \\
\hline & Eq1 & Eq2 & Eq3 & Eq4 & Eq5 & Eq6 & Eq1 & Eq2 & Eq3 & Eq4 & Eq5 & Eq6 & & \\
\hline $\mathrm{Xa}$ & 25 & 35 & NA & NA & NA & 50 & 1700 & 2500 & NA & NA & NA & 1720 & 500 & 2000 \\
\hline $\mathrm{xb}$ & 30 & 30 & NA & NA & NA & 35 & 1905 & 2200 & NA & NA & NA & 1910 & 450 & 1800 \\
\hline $\mathrm{Xc}$ & 25 & 28 & NA & NA & NA & 22 & 2210 & 3000 & NA & NA & NA & 2250 & 480 & 1920 \\
\hline $\mathrm{Xd}$ & 18 & NA & 20 & NA & 20 & NA & 1915 & NA & 1900 & NA & 2500 & NA & 625 & 2500 \\
\hline $\mathrm{Xe}$ & 14 & NA & 25 & 41 & NA & NA & 2420 & NA & 2300 & 2460 & NA & NA & 312 & 1248 \\
\hline$x f$ & 25 & NA & 26 & 28 & NA & NA & 1780 & NA & 2600 & 1700 & NA & NA & 220 & 880 \\
\hline $\mathrm{Xg}$ & 20 & NA & 21 & NA & 36 & NA & 1910 & NA & 2800 & NA & 1560 & NA & 200 & 800 \\
\hline $\mathrm{Xh}$ & 15 & NA & 32 & 32 & NA & NA & 1860 & NA & 1600 & 1850 & NA & NA & 400 & 1600 \\
\hline $\begin{array}{l}\text { Failure Rate } \\
M T R R+M T B F\end{array}$ & $4 \%$ & $11 \%$ & $6 \%$ & $12 \%$ & $9 \%$ & $14 \%$ & & & & citus & ailablo & $\mathrm{h}$ & day & \\
\hline
\end{tabular}

The objective of Scenario 2 is to demonstrate the impacts on lead time and inprocess inventory with the reduction of manufacturing batches, setup times, and punctuality of deliveries in the evaluated indicators.

For the development of Scenario 3, the same database as Scenario 2 was used, changing only the different data on failure rate and the available capacity among 
the evaluated equipment. The structured data for the simulation of Scenario 3 are described in Table 5.

Table 5. Scenario 3 for the application of Virtual Reality in the teaching processes of production planning and control

\begin{tabular}{|c|c|c|c|c|c|c|c|c|c|c|c|c|c|c|}
\hline & \multicolumn{6}{|c|}{ Processing times (seconds) } & \multicolumn{6}{|c|}{ Changeover times (seconds) } & \multirow{2}{*}{$\begin{array}{c}\text { Daily } \\
\text { Demand }\end{array}$} & \multirow{2}{*}{ Batch size } \\
\hline & Eq1 & $\mathrm{Eq} 2$ & $\mathrm{Eq} 3$ & $\mathrm{Eq} 4$ & Eq5 & Eq6 & Eq1 & $\mathrm{Eq} 2$ & $\mathrm{Eq} 3$ & Eq4 & $\mathrm{Eq} 5$ & Eq6 & & \\
\hline $\mathrm{Xa}$ & 25 & 35 & NA & NA & NA & 50 & 1700 & 2500 & NA & NA & NA & 1720 & 500 & 2000 \\
\hline $\mathrm{xb}$ & 30 & 30 & NA & NA & NA & 35 & 1905 & 2200 & NA & NA & NA & 1910 & 450 & 1800 \\
\hline$X_{c}$ & 25 & 28 & NA & NA & NA & 22 & 2210 & 3000 & NA & NA & NA & 2250 & 480 & 1920 \\
\hline $\mathrm{xd}$ & 18 & NA & 20 & NA & 20 & NA & 1915 & NA & 1900 & NA & 2500 & NA & 625 & 2500 \\
\hline $\mathrm{Xe}$ & 14 & NA & 25 & 41 & NA & NA & 2420 & NA & 2300 & 2460 & NA & NA & 312 & 1248 \\
\hline$X f$ & 25 & NA & 26 & 28 & NA & NA & 1780 & NA & 2600 & 1700 & NA & NA & 220 & 880 \\
\hline $\mathrm{Xg}$ & 20 & NA & 21 & NA & 36 & NA & 1910 & NA & 2800 & NA & 1560 & NA & 200 & 800 \\
\hline $\mathrm{Xh}$ & 15 & NA & 32 & 32 & NA & NA & 1860 & NA & 1600 & 1850 & NA & NA & 400 & 1600 \\
\hline $\begin{array}{l}\text { Failure Rate } \\
\text { MTTR + MTBF }\end{array}$ & $3 \%$ & $8 \%$ & $4 \%$ & $8 \%$ & $7 \%$ & $10 \%$ & & 010 & $\begin{array}{l}\text { Eq1 - } \\
\text { / Eq4 } \\
q 5-\mathrm{Av}\end{array}$ & ailabl & $\begin{array}{l}\text { Availa } \\
\text { capac }\end{array}$ & $\begin{array}{l}\text { e cap } \\
\text { of } 8\end{array}$ & $\begin{array}{l}\text { ours a day } \\
\text { ty of } 16 \text { hou } \\
\text { urs per day }\end{array}$ & a day \\
\hline
\end{tabular}

In Scenario 3, there was a reduction in the failure rate of approximately $35 \%$. The available capacity was modified in five of the six pieces of equipment in this production system, in which Eq1 was kept available 24 hours a day; the Eq2 / Eq3 / Eq4 / Eq6 available 16 hours a day; and Eq5 available for 8 hours a day. The reduction in the failure rate increases the availability of the equipment to process materials, and the difference in the available capacity of the equipment generates high indexes of stocks awaiting processing and shortage of materials for later processes.

Scenario 4 was elaborated from the previous scenario, changing processing times and material demand parameters to assess the impacts of these parameters on the indicators of manufacturing lead time, stock in process, efficiency, and punctuality of deliveries. The parameters used are displayed in Table 6.

Table 6. Scenario 4 for the application of virtual reality in the teaching processes of production planning and control

\begin{tabular}{|c|c|c|c|c|c|c|c|c|c|c|c|c|c|c|}
\hline & \multicolumn{6}{|c|}{ Processing times (seconds) } & \multicolumn{6}{|c|}{ Changeover times (seconds) } & \multirow{2}{*}{$\begin{array}{c}\text { Daily } \\
\text { Demand }\end{array}$} & \multirow{2}{*}{ Batch size } \\
\hline & Eq1 & Eq2 & $\mathrm{Eq} 3$ & Eq4 & Eq5 & Eq6 & Eq1 & Eq2 & Eq3 & Eq4 & Eq5 & Eq6 & & \\
\hline $\mathrm{Xa}$ & 20 & 28 & NA & NA & NA & 40 & 1700 & 2500 & NA & NA & NA & 1720 & 450 & 1800 \\
\hline $\mathrm{Xb}$ & 25 & 25 & NA & NA & NA & 28 & 1905 & 2200 & NA & NA & NA & 1910 & 400 & 1600 \\
\hline $\mathrm{Xc}$ & 20 & 22 & NA & NA & NA & 17 & 2210 & 3000 & NA & NA & NA & 2250 & 430 & 1720 \\
\hline$x d$ & 14 & NA & 16 & NA & 16 & NA & 1915 & NA & 1900 & NA & 2500 & NA & 570 & 2280 \\
\hline $\mathrm{Xe}$ & 10 & NA & 20 & 32 & NA & NA & 2420 & NA & 2300 & 2460 & NA & NA & 280 & 1120 \\
\hline$x f$ & 19 & NA & 21 & 22 & NA & NA & 1780 & NA & 2600 & 1700 & NA & NA & 200 & 800 \\
\hline $\mathrm{Xg}$ & 17 & NA & 18 & NA & 29 & NA & 1910 & NA & 2800 & NA & 1560 & NA & 180 & 720 \\
\hline $\mathrm{Xh}$ & 13 & NA & 23 & 25 & NA & NA & 1860 & NA & 1600 & 1850 & NA & NA & 360 & 1440 \\
\hline $\begin{array}{l}\text { Failure Rate } \\
\text { MTTR + MTBF }\end{array}$ & $3 \%$ & $8 \%$ & $4 \%$ & $8 \%$ & $7 \%$ & $10 \%$ & & $2 / \mathrm{Eq}$ & $\begin{array}{l}\text { Eq1 - } \\
\text { / Eq4 } \\
\text { Eq5 - A }\end{array}$ & $\begin{array}{l}\text { Capacity } \\
\text { / Eq6-A } \\
\text { ailable c }\end{array}$ & $\begin{array}{l}\text { avail } \\
\text { Availa } \\
\text { capaci }\end{array}$ & $\begin{array}{l}\text { le } 24 \\
\text { cap } \\
\text { of } 8\end{array}$ & $\begin{array}{l}\text { urs a day } \\
\text { y of } 16 \text { hou } \\
\text { ars per day }\end{array}$ & s a day \\
\hline
\end{tabular}


In the scenario described in Table 6, there was a reduction in cycle times by approximately $20 \%$ and demand by $10 \%$ compared to that described in Table 5 . The reduction in cycle times increases in the quantities produced in the same period, but negatively impacts the manufacturing lead time and an inventory increase. The demand reduction reinforces this impact because the consumption of subsequent processes is lower, generating greater inventory in the process.

For elaborating scenarios 5 and 6, we tried to change the production planning decision and applied the production logic pulled into the system, in which the decision of what to produce depends on the planned stock level between operations. For the execution of Scenario 5, it was decided to use the same data as Scenario 1, but with supermarkets between operations. For Scenario 6, the data is identical to Scenario 4, also with supermarkets between operations. The layout of the production environment and the material flow for Scenarios 5 and 6 are shown in Figure 4.

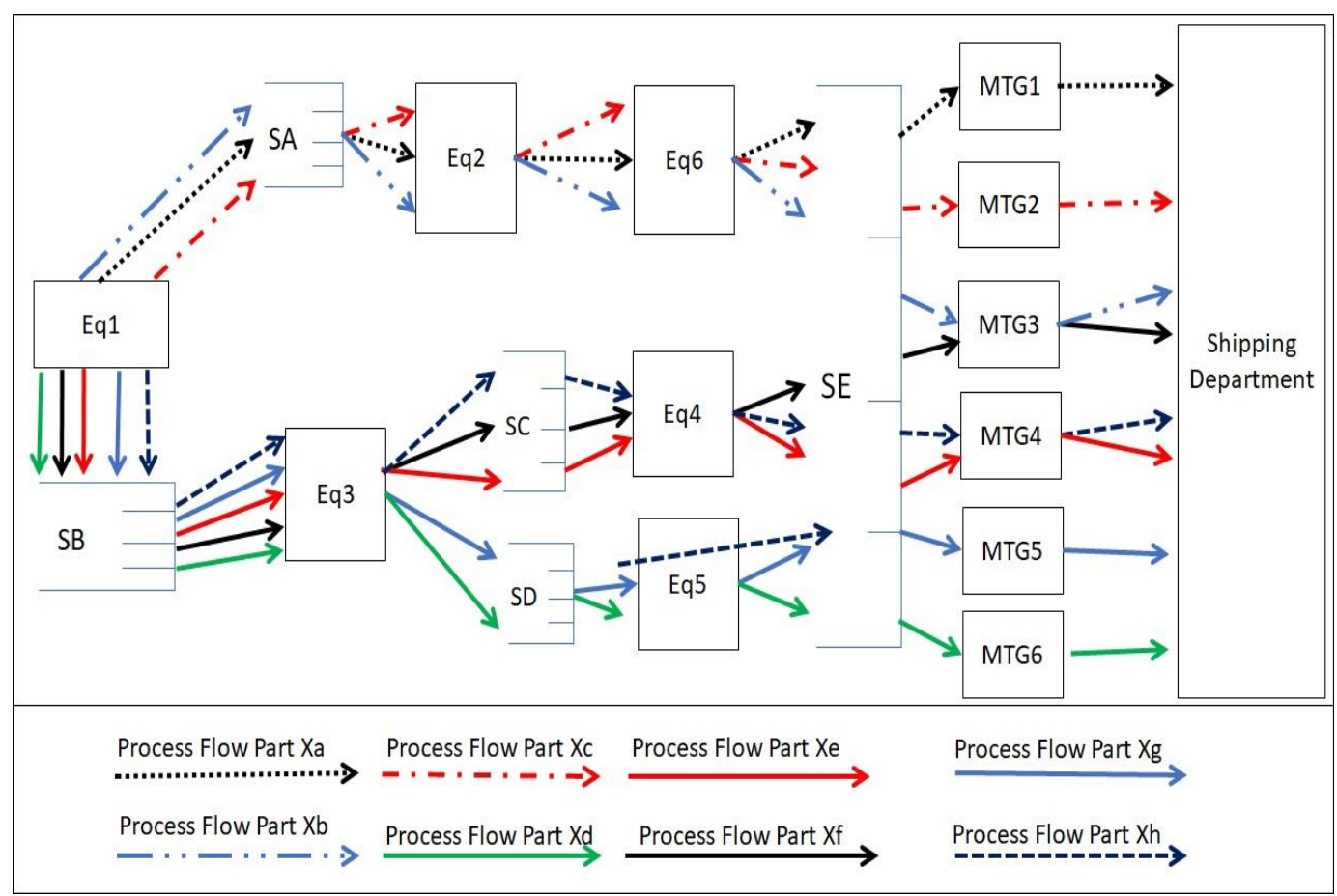

Figure 4. Layout of the production environment and material flow for Scenarios 5 and 6

When evaluating the layout and material flow as shown in Figure 4, it is possible to notice a change compared to that presented in Figure 2. That is, it appears that Eq1 has its production managed by the stock levels of supermarkets called SA and SB. The inventory levels demand the production of Eq3 of supermarkets SC and SD. The production of the Eq4, Eq5, and Eq2 equipment (which has a continuous flow with the Eq6 equipment) is managed by the inventory level of the SE supermarket. The data defined for Scenario 5 are described in Table 7.

Scenario 5 uses rules to control inventory levels in supermarkets to determine which components should be manufactured. When any part reaches the minimum inventory level, a new manufacturing batch can be started. The level 
of in-process inventory will be reduced because the equipment worked less, even with production batches much larger than the daily demand (production batches with seven days of daily demands). On the other hand, the equipment efficiency will be reduced due to the demand lack for production in some moments. In Scenario 6, data from Scenario 4 of virtual reality simulation were used, according to Table 8.

Table 7. Scenario 5 for the application of virtual reality in the teaching processes of production planning and control

\begin{tabular}{|c|c|c|c|c|c|c|c|c|c|}
\hline \multicolumn{5}{|c|}{ Supermarket SA } & \multicolumn{5}{|c|}{ Supermarket SC } \\
\hline Equipment & $\begin{array}{c}\text { Daily } \\
\text { Demand }\end{array}$ & $\begin{array}{l}\text { Estoque } \\
\text { Mínimo } \\
\end{array}$ & $\begin{array}{l}\text { Estoque } \\
\text { Máximo }\end{array}$ & Batch size & Equipment & \begin{tabular}{|c|} 
Daily \\
Demand \\
\end{tabular} & $\begin{array}{l}\text { Estoque } \\
\text { Mínimo }\end{array}$ & $\begin{array}{l}\text { Estoque } \\
\text { Máximo }\end{array}$ & Batch size \\
\hline Xa & 500 & 0 & 3500 & 3500 & $\mathrm{Xe}$ & 312 & 0 & 2184 & 2184 \\
\hline $\mathrm{Xb}$ & 450 & 0 & 3150 & 3150 & $X f$ & 220 & 0 & 770 & 770 \\
\hline$X_{c}$ & 480 & 0 & 3360 & 3360 & $\mathrm{Xh}$ & 400 & 0 & 2800 & 2800 \\
\hline \multicolumn{5}{|c|}{ Supermarket SB } & \multicolumn{5}{|c|}{ Supermarket SD } \\
\hline Equipment & $\begin{array}{c}\text { Daily } \\
\text { Demand }\end{array}$ & \begin{tabular}{|l|} 
Estoque \\
Mínimo \\
\end{tabular} & $\begin{array}{l}\text { Estoque } \\
\text { Máximo } \\
\end{array}$ & Batch size & Equipment & \begin{tabular}{|c|} 
Daily \\
Demand \\
\end{tabular} & $\begin{array}{l}\text { Estoque } \\
\text { Mínimo }\end{array}$ & $\begin{array}{l}\text { Estoque } \\
\text { Máximo }\end{array}$ & Batch size \\
\hline$\frac{x d}{x_{e}}$ & $\frac{625}{312}$ & $\frac{0}{0}$ & $\frac{4375}{2184}$ & $\frac{4375}{2184}$ & $x d$ & 625 & 0 & 4375 & 4375 \\
\hline$x f$ & 220 & 0 & 1540 & 1540 & \multirow{3}{*}{$\mathrm{xg}$} & \multirow{3}{*}{200} & \multirow{3}{*}{0} & \multirow{3}{*}{1400} & \multirow{3}{*}{1400} \\
\hline $\mathrm{Xg}$ & 200 & 0 & 1400 & 1400 & & & & & \\
\hline $\mathrm{Xh}$ & 400 & 0 & 2800 & 2800 & & & & & \\
\hline \multicolumn{5}{|c|}{ Supermarket SE } & \multirow{10}{*}{\multicolumn{5}{|c|}{$\begin{array}{l}1 \text { - } 24 \text { hour capacity available per day } \\
2 \text { - Failure rate - Eq1 -4\%; EQ2 - 11\%; Eq3 - 6\%; Eq4; } \\
12 \% ; \text { Eq5 - } 9 \% \text { and Eq6 - } 14 \% \text {. } \\
3 \text { - All stock security in the system is organized in } \\
\text { Supermarket E } \\
4 \text { - The equipment will always consume all available } \\
\text { stock in your supply supermarket. }\end{array}$}} \\
\hline Equipment & $\begin{array}{c}\text { Daily } \\
\text { Demand }\end{array}$ & $\begin{array}{l}\text { Estoque } \\
\text { Mínimo }\end{array}$ & $\begin{array}{l}\text { Estoque } \\
\text { Máximo }\end{array}$ & Batch size & & & & & \\
\hline Xa & 500 & 1000 & 4500 & 3500 & & & & & \\
\hline $\mathrm{Xb}$ & 450 & 900 & 4050 & 3150 & & & & & \\
\hline$X_{c}$ & 480 & 960 & 4320 & 3360 & & & & & \\
\hline$x d$ & 625 & 1250 & 5625 & 4375 & & & & & \\
\hline $\mathrm{Xe}$ & 312 & 624 & 2808 & 2184 & & & & & \\
\hline Xf & 220 & 440 & 1980 & 1540 & & & & & \\
\hline $\mathrm{Xg}$ & 200 & 400 & 1800 & 1400 & & & & & \\
\hline $\mathrm{Xh}$ & 400 & 800 & 3600 & 2800 & & & & & \\
\hline
\end{tabular}

Similar to Scenario 5, Scenario 6 brings all the production planning management related to the supermarket stock levels. Unlike the previous scenario, however, this one has setup times, maximum stock levels, and smaller production batches, and the production lead time and stock in process indicators show considerable improvements. Indicators of equipment efficiency and punctuality of delivery will only be possible if they are evaluated after the simulation of the model in virtual reality, using the software chosen for this task. All theoretical evidence indicates that punctuality of delivery should have better rates in the leanest scenarios (shorter setup times, shorter cycle times, shorter production batches), but the quantification of these rates is possible only after the scenarios simulation. 
Table 8. Scenario 6 for the application of virtual reality in the teaching processes of production planning and control

\begin{tabular}{|c|c|c|c|c|c|c|c|c|c|}
\hline \multicolumn{5}{|c|}{ Supermarket SA } & \multicolumn{5}{|c|}{ Supermarket SC } \\
\hline Equipamentos & \begin{tabular}{|c|} 
Demanda \\
Diária \\
\end{tabular} & $\begin{array}{l}\text { Estoque } \\
\text { Mínimo }\end{array}$ & $\begin{array}{l}\text { Estoque } \\
\text { Máximo }\end{array}$ & $\begin{array}{l}\text { Lote de } \\
\text { Fabricação }\end{array}$ & Equipamentos & \begin{tabular}{|c|} 
Demanda \\
Diária \\
\end{tabular} & \begin{tabular}{|l} 
Estoque \\
Mínimo \\
\end{tabular} & \begin{tabular}{|l|} 
Estoque \\
Máximo \\
\end{tabular} & $\begin{array}{c}\text { Lote de } \\
\text { Fabricação } \\
\end{array}$ \\
\hline$X_{a}$ & 450 & 0 & 1800 & 1800 & $\mathrm{Xe}$ & 280 & 0 & 1120 & 1120 \\
\hline $\mathrm{Xb}$ & 400 & 0 & 1600 & 1600 & Xf & 200 & 0 & 800 & 800 \\
\hline$x_{c}$ & 430 & 0 & 1720 & 1720 & $\mathrm{Xh}$ & 360 & 0 & 1440 & 1440 \\
\hline \multicolumn{5}{|c|}{ Supermarket SB } & \multicolumn{5}{|c|}{ Supermarket SD } \\
\hline Equipamentos & \begin{tabular}{|c|} 
Demanda \\
Diária \\
\end{tabular} & $\begin{array}{l}\text { Estoque } \\
\text { Mínimo }\end{array}$ & $\begin{array}{l}\text { Estoque } \\
\text { Máximo }\end{array}$ & $\begin{array}{c}\text { Lote de } \\
\text { Fabricação }\end{array}$ & Equipamentos & \begin{tabular}{|c|} 
Demanda \\
Diária \\
\end{tabular} & \begin{tabular}{|l} 
Estoque \\
Mínimo \\
\end{tabular} & \begin{tabular}{|l|} 
Estoque \\
Máximo
\end{tabular} & $\begin{array}{c}\text { Lote de } \\
\text { Fabricação }\end{array}$ \\
\hline$x d$ & 570 & 0 & 2280 & 2280 & \multirow{2}{*}{$x d$} & \multirow{2}{*}{570} & \multirow{2}{*}{0} & \multirow{2}{*}{2280} & \multirow{2}{*}{2280} \\
\hline $\mathrm{xe}$ & 280 & 0 & 1120 & 1120 & & & & & \\
\hline$x f$ & 200 & 0 & 800 & 800 & & \multirow{3}{*}{180} & \multirow{3}{*}{0} & \multirow{3}{*}{720} & \multirow{3}{*}{720} \\
\hline $\mathrm{xg}$ & 180 & 0 & 720 & 720 & & & & & \\
\hline $\mathrm{Xh}$ & 360 & 0 & 1440 & 1440 & & & & & \\
\hline \multicolumn{5}{|c|}{ Supermarket SE } & \multirow{10}{*}{\multicolumn{5}{|c|}{$\begin{array}{l}1 \text {-Eq1 - Capacity available } 24 \text { hours a day } \\
\text { Eq2 / Eq3 / Eq4 / Eq6 - Available capacity of } 16 \text { hours a day } \\
\text { Eq5 - Available capacity of } 8 \text { hours per day } \\
2 \text { - Failure rate - Eq1 -3\%; EQ2 - 8\%; Eq3 - 4\%; Eq4; 8\%; Eq5 } \\
\text { - } 7 \% \text { and Eq6 - 10\%. } \\
3 \text { - All stock security in the System is organized in } \\
\text { Supermarket E } \\
4 \text { - The Equipment will always consume all available stock } \\
\text { in your supply supermarket. }\end{array}$}} \\
\hline Equipamentos & \begin{tabular}{|c|} 
Demanda \\
Diária \\
\end{tabular} & $\begin{array}{l}\text { Estoque } \\
\text { Mínimo }\end{array}$ & $\begin{array}{l}\text { Estoque } \\
\text { Máximo }\end{array}$ & $\begin{array}{l}\text { Lote de } \\
\text { Fabricação }\end{array}$ & & & & & \\
\hline$X_{a}$ & 450 & 900 & 2700 & 1800 & & & & & \\
\hline $\mathrm{Xb}$ & 400 & 800 & 2400 & 1600 & & & & & \\
\hline$X_{c}$ & 430 & 860 & 2580 & 1720 & & & & & \\
\hline$x d$ & 570 & 1140 & 3420 & 2280 & & & & & \\
\hline $\mathrm{xe}$ & 280 & 560 & 1680 & 1120 & & & & & \\
\hline $\mathrm{xf}$ & 200 & 400 & 1200 & 800 & & & & & \\
\hline $\mathrm{xg}$ & 180 & 360 & 1080 & 720 & & & & & \\
\hline $\mathrm{xh}$ & 360 & 720 & 2160 & 1440 & & & & & \\
\hline
\end{tabular}

\section{Analysis of Results}

It appears that the application of virtual reality in the teaching-learning processes is used in several areas of performance, demonstrating superior learning results by students who use virtual reality when compared to those who only use the traditional teaching method. This application is verified, for example, in research by the authors like Quadir et al. (2019), Li et al. (2018), and Skarka et al. (2015). They demonstrated the efficiency of the approach and emphasized that it is essential to develop a learning environment that generates the opportunity to increase learning through virtual reality to have a relevant result.

Deciding on the production planning and control area generates unprecedented research in an area of great relevance in production engineering. According to Lage Junior (2019), the processes in this area impact various organizational indicators, such as on-time delivery rate, inventory levels, idleness or lack of production capacity, organization of internal work at factories, and direct activities of purchasing, receiving, and storing materials. In addition, the research opportunity presented by Anjos et al. (2020) demonstrated the importance of creating differentiated teaching environments to generate the most significant possible knowledge for students. In addition, Kanakana- 
Katumba and Maladzhi (2019) emphasized that the cognitive environment must consider some characteristics to be elaborated. In the scenarios proposed by the authors, an environment with an experimental approach (through virtual reality) is perceived because it generates for the student the opportunity to practice, the concepts and theories developed in a practical way.

The scenarios to be applied in virtual reality were organized through a mix of guidelines. According to the guidelines change, there was a change in some indicators resulting from production planning and control. The relevance of each scenario can be highlighted; in Scenario 1, the impacts of large production lots and transfers between the equipment and the high setup times are shown; in Scenario 2, data similar to scenario 1 are applied, but with smaller production batches and setup time. When comparing the results, impacts of indicators are perceived, such as reducing production lead time, inventory levels in processes, and punctuality of delivery. Similarly, Scenario 3 uses the reference data from Scenario 2 but with a reduction in the available capacity for production (reduction of the available time). Through this action, it will be possible to evaluate improvements in the efficiency indexes. Scenario 4 was elaborated on data from the previous scenario, but with reduced processing times for manufactured materials and reduced demand. This change influences all the indicators monitored during the virtual reality simulation. Scenarios 5 and 6 use the data applied in Scenarios 1 and 4, respectively, however, with a fundamental change, the production planning system starts to be drawn from the inventory levels for the assembly processes (SE supermarket).

The validity of this model is based on the relationship between the factors that make up the production system, for example, fixed production batches or dynamic production batches (Brahimi et al., 2017; Suzanne et al., 2020), organization of production systems for discrete, continuous or project production (Armbruster et al., 2012; La Marca et al., 2010), equipment failure rate (Göttlich \& Knapp, 2019), setup times and manufacturing lead time (Allahverdi \& Soroush, 2008), processing time and take time (Ayough et al., 2020), production capacity available for the execution of the planned production (Babaei et al., 2014; Oliveira \& Costa, 2018), organization of the layout, according to the processing and material flow scripts (Caicedo et al., 2019) and the evaluation the performance indicators of a production system, the results of decisions of the production sequencing impact in the indicators, for example, delivery attendant, delay of order, production advance, production lead time, number of overdue orders, inventory in process, and use of equipment (Lustosa et al., 2008).It is noticed that, in addition to the realism of the virtual environment Schlemmer and Backes (2015), the benefits of the training environment in virtual reality Duncan et al. (2012) and the cognition generated by the training environment Lefrançois (2016), scenarios proposed for application in virtual reality manage to articulate the guidelines that influence the planning and control of production, impact the monitored indicators, and finally support students to develop more clearly and concisely knowledge on the topic addressed. 


\section{Conclusion}

The discussion on the teaching-learning processes in production planning and control allows us to see that the combination of scenarios with virtual reality and the focus of the cognition of the teaching environment generate a combination of factors that, if well-organized, lead to positive results in student learning through the combination of dynamic data simulation and virtual reality, in which the virtual world brings students closer to the studied subject. The different scenarios provide students with two opportunities: (i) the ability to understand which factors related to the production system influence the production sequencing indicators, and (ii) with what impact each factor influences these evaluated indicators. Scenario 1 demonstrates the impact of factors (large production batches and high setup times) on the analyzed indicators and how changing the factors applied to scenario 2 improves the indicators. Scenarios 3 and 4 discuss other factors (failure rate and available capacity) and how the quantitative change of factors influences the evaluated indicators. Finally, they change the logic applied to production sequencing, transforming it into a pull system, in which production is managed by demand and all the benefits that this logic brings to the indicators of the production sequencing process.

\section{Limitations}

Some limitations of the research are the lack of variation in process flows and factory layout and the lack of application of variability in the data used in the simulation, such as, production times, failure rates, setup times, and demand, because it is known that these types of data are usually not static.

\section{Future Research}

For future research, the authors suggest testing other production sequencing approaches, such as drum, lung, and rope (from the theory of constraints), and developing a system with production for product stock by adding to this decision the variability of the data of the applied factors, for example, setup times, capacity and failure rate, to the sequencing of production.

\section{References}

ABEPRO. (2008). Áreas e Sub-áreas de Engenharia de Produção [Production engineering areas and subareas] http:/ / www.abepro.org.br/interna.asp? $p=399 \& m=424 \& s s=1 \& c=362$

Akbulut, A., Catal, C., \& Yildiz, B. (2018). On the effectiveness of virtual reality in the education of software engineering. Computer Applications in Engineering Education, 26(4), 918-927. https://doi.org/10.1002/cae.21935

Allahverdi, A., \& Soroush, H. M. (2008). The significance of reducing setup times/setup costs. European Journal of Operational Research, 187(3), 978-984. https://doi.org/10.1016/j.ejor.2006.09.010

Anjos, F. E. V. dos, Rocha, L. A. O., Silva, D. O. da, \& Pacheco, R. (2020). Virtual and augmented reality application in production engineering teaching-learning processes. Production, 30, 1-16. https://doi.org/10.1590/0103-6513.20190088

Armbruster, D., Fonteijn, J., \& Wienke, M. (2012). Modeling production planning and transient clearing functions. Logistics Research, 5(3), 133-139. https:// doi.org/10.1007/s12159-012-0087-8 
Ayough, A., Zandieh, M., \& Farhadi, F. (2020). Balancing, sequencing, and job rotation scheduling of a U-shaped lean cell with dynamic operator performance. $\begin{array}{llll}\text { Computers and Industrial Engineering, } & 143 .\end{array}$ https:// doi.org/10.1016/j.cie.2020.106363

Babaei, M., Mohammadi, M., \& Ghomi, S. M. T. F. (2014). A genetic algorithm for the simultaneous lot sizing and scheduling problem in capacitated flow shop with complex setups and backlogging. The International Journal of Advanced Manufacturing Technology, 70, 125-134. https://doi.org/10.1007/s00170-013$5252-\mathrm{y}$

Bates, A. W. (2015). Teaching in a digital age: Guidelines for designing teaching and learning (1st ed.). Tony Bates Associates Ltd.

Brahimi, N., Absi, N., Dauzère-Pérès, S., \& Nordli, A. (2017). Single-item dynamic lotsizing problems: An updated survey. European Journal of Operational Research, 263(3), 838-863. https://doi.org/10.1016/j.ejor.2017.05.008

Caicedo, A. J., Parra, J. W., \& Rivera, L. (2019). Mathematical model for production sequencing in a manufacturing company. Journal of Physics: Conference Series, 1388(1). https:// doi.org/10.1088/1742-6596/1388/1/012001

Corrêa, Henrique Luiz; Gianese, Irineu Gustavo Nogueira; Caon, M. (2019). Planejamento, programação e controle da produção: MRP II / ERP :Conceitos, uso e implantação : Base para SAP, oracle applications e outros softwaresintegrados de gestão [Production planning, scheduling and control: MRP II / ERP: Concepts, use and implementation: Basis for SAP, oracle applications and other integrated management software] (6 $6^{\text {th }}$ ed.). Atlas.

Crawley, E., Hosoi, A., Long, G., Kassis, T., Dickson, W., \& Mitra, A. (2019, June). Moving forward with the New Engineering Education Transformation (NEET) program at MIT - building community, developing projects, and connecting with industry. 2019 Paper presented at ASEE Annual Conference \& Exposition Proceedings, Tampa, Florida. https:/ / doi.org/10.18260/1-2--33124

Duncan, I., Miller, A., \& Jiang, S. (2012). A taxonomy of virtual worlds usage in education. British Journal of Educational Technology, 43(6), 949-964. https://doi.org/10.1111/j.1467-8535.2011.01263.x

Fonseca, D. E., Redondo, E. D., \& Valls, F. (2016). Motivación y mejora académica utilizando realidad aumentada para el estudio de modelos tridimensionales arquitectónicos [Motivation and academic improvement using augmented reality for the study of architectural three-dimensional models]. Education in the Knowledge Society (EKS), 17(1), 45-64. https://doi.org/10.14201/eks20161714564

Frevert, M., \& Di Fuccia, D.-S. (2019). Virtual reality as a means of teaching contemporary chemistry. Proceedings of the 2019 The 3rd International Conference on Digital Technology in Education, 34-38. https:// doi.org/10.1145/3369199.3369218

Gilbert, J. K. (2004). Models and modelling: Routes to more authentic science education. International Journal of Science and Mathematics Education, 2(2), 115-130. https://doi.org/10.1007/s10763-004-3186-4

Göttlich, S., \& Knapp, S. (2019). Load-dependent machine failures in production network models. SIAM Journal on Applied Mathematics, 79(4), 1197-1217. https://doi.org/10.1137/18M1193177

Grodotzki, J., Ortelt, T. R., \& Tekkaya, A. E. (2018). Remote and virtual labs for engineering education 4.0: Achievements of the ELLI project at the TU Dortmund university. Paper presented at the $26^{\text {th }}$ SME North American Manufacturing Research Conference,NAMRC 46 ,Texas,

USA. https://doi.org/10.1016/j.promfg.2018.07.126 
Habib, A., Jilcha, K., \& Berhan, E. (2015). Performance Improvement by Scheduling Techniques: A Case of Leather Industry Development Institute. Paper presented at Afro-European Conference for Industrial Advancement,261-269). https://doi.org/10.1007/978-3-319-13572-4_21

Hwang, G.-J., Chiu, L.-Y., \& Chen, C.H. (2015). A contextual game-based learning approach to improving students' inquiry-based learning performance in social studies courses. Computers \& Education, 81, 13-25. https://doi.org/10.1016/j.compedu.2014.09.006

Inayat, I., Inayat, Z., \& ul Amin, R. (2016). Teaching and learning object-oriented analysis and design with $3 \mathrm{D}$ game. Proceedings of $14^{\text {th }}$ International Conference on Frontiers of Information Technology 46-51. https://doi.org/10.1109/FIT.2016.16

Kanakana-Katumba, M. G., \& Maladzhi, R. (2019). Online learning approaches for science, engineering and technology in distance education. Paper presented at the IEEE International Conference on Industrial Engineering and Engineering Management, 930-934. https://doi.org/10.1109/IEEM44572.2019.8978892

National Association of State Directors of Career Technical Education Consortium , \& Achieve. (2015, November 5). Building a strong relationship between competency-based pathways and career technical education [Blog post]. https://careertech.org/sites/default/files/CTECompetencyBasedPathways.pdf

La Marca, M., Armbruster, D., Herty, M., \& Ringhofer, C. (2010). Control of continuum models of production systems. IEEE Transactions on Automatic Control, 55(11), 2511-2526. https://doi.org/10.1109/TAC.2010.2046925

Lage Junior, M. (2019). Planejamento e controle da produção: teoria e prática [Production planning and control: Theory and practice] (1 ${ }^{\text {st }}$ ed.). LTC.

Lamb, R., Antonenko, P., Etopio, E., \& Seccia, A. (2018). Comparison of virtual reality and hands on activities in science education via functional near infrared spectroscopy. Computers $\mathcal{E}$ Education, 124, 14-26. https:// doi.org/10.1016/j.compedu.2018.05.014

Laseinde, O. T., Adejuyigbe, S. B., Mpofu, K., \& Campbell, H. M. (2016). Educating tomorrows engineers: Reinforcing engineering concepts through Virtual Reality (VR) teaching aid. Paper presented at the IEEE International Conference on Industrial Engineering and Engineering Management, IEEM 2015, 2016. https://doi.org/10.1109/IEEM.2015.7385894

Lefrançois, G. R. (2016). Teorias da Aprendizagem: O que o professor disse [Theories of human learning] (6 $6^{\text {th }}$ ed.). Cengage Learning.

Li, Y., Zhang, D., Guo, H., \& Shen, J. (2018). A novel virtual simulation teaching system for numerically controlled machining. International Journal of Mechanical Engineering Education, 46(1), 64-82. https://doi.org/10.1177/0306419017715426

Lustosa, L. J., Mesquita, M. A., Quelhas, G., Osvaldo, L., \& Oliveira, R. J. de. (2008). Planejamento e controle da produção [Planning and production control] ( $1^{\mathrm{st}} \mathrm{ed}$.). Elsevier.

Martins, V. F., \& Guimarães, M. de P. (2012). Desafios para o uso de Realidade Virtual e Aumentada de maneira efetiva no ensino [Challenges for using virtual and augmented reality effectively in teaching]. Anais Do Workshop de Desafios Da Computação Aplicada à Educação[Proceedings of the Challenges of Computing Applied to Education Workshop], 100-109.

Mayne, R., \& Green, H. (2020). Virtual reality for teaching and learning in crime scene investigation. Science and Justice, 60(5), 466-472. https://doi.org/10.1016/j.scijus.2020.07.006 
Mestrinho, N., \& Cavadas, B. (2018). Innovation in teacher education: An integrative approach to teaching and learning science and mathematics. Proceedings, 2(21), 1343. https://doi.org/10.3390/proceedings2211343

Mizukami, M. da G. N. (1992). Ensino: A Abordagens do Processo [Teaching: Process Approaches] (1 ${ }^{\text {st }}$ ed.). LTC.

Oliveira, F. S., \& Costa, M. L. G. (2018). Capacity expansion under uncertainty in an oligopoly using indirect reinforcement-learning. European Journal of Operational Research, 267(3), 1039-1050. https:// doi.org/10.1016/j.ejor.2017.11.013

Prensky, M. (2001). Digital natives, digital immigrants part 1. On the Horizon, 9(5), 1-6. https:// doi.org/10.1108/10748120110424816

Quadir, B., Yang, J. C., \& Chen, N. S. (2019). The effects of interaction types on learning outcomes in a blog-based interactive learning environment. Interactive Learning Environments, 1-14. https:/ / doi.org/10.1080/10494820.2019.1652835

Sánchez, A., Redondo, E., Fonseca, D., \& Navarro, I. (2015). Academic performance assessment using augmented reality in engineering degree course. Proceedings Frontiers in Education Conference, 1-7. https:// doi.org/10.1109/FIE.2014.7044238

Santos, J. (2006). Teorias da aprendizagem: Comportamentalista, cognitivista e humanista [Learning theories: Behaviorist, cognitivist and humanist]. Revista Cientifica Sigma [Sigma Scientific Journal], 2, 97-111.

Schlemmer, E., \& Backes, L. (2015). Learning in Metaverses. IGI Global. https://doi.org/10.4018/978-1-4666-6351-0

Shirazi, A., \& Behzadan, A. H. (2015). Content delivery using augmented reality to enhance students' performance in a building design and assembly project. Advances in Engineering Education, 4(3), 1-24.

Skarka, W., Wylezol, M., Januszka, M., Rzydzik, S., \& Targosz, M. (2015). Improving the ability of future engineers by using advanced interactive 3D techniques in education. In R. Curran, N. Wognum, M. Borsato,J. Stjepandic \& W.J.C. Verhagen (Eds.), Transdisciplinary lifecycle analysis of systems ( pp. 647-656). IOS Press. https://doi.org/10.3233/978-1-61499-544-9-647

Smutny, P., Babiuch, M., \& Foltynek, P. (2019). A review of the virtual reality applications in education and training. Proceedings of the 2019 20th International Carpathian Control Conference, ICCC. https://doi.org/10.1109/CarpathianCC.2019.8765930

Soudien, C. (2010). Transformation in higher education- A briefing paper. Policy Studies Journal, 44(1), 29. https:// doi.org/10.1007/1-4020-4006-7

Suzanne, E., Absi, N., Borodin, V., \& van den Heuvel, W. (2020). A single-item lot-sizing problem with a by-product and inventory capacities. European Journal of Operational Research, 287(3), 844-855. https:// doi.org/10.1016/j.ejor.2020.05.017

Tsai, C. W., Shen, P. Di, \& Lu, Y. J. (2015). The effects of problem-based learning with flipped classroom on elementary students' computing skills: A case study of the production of Ebooks. International Journal of Information and Communication Technology Education, 11(2), 32-40. https:// doi.org/10.4018/ijicte.2015040103

Wang, H.-Y., Liu, G.-Z., \& Hwang, G.-J. (2017). Integrating socio-cultural contexts and location-based systems for ubiquitous language learning in museums: A state of the art review of 2009-2014. British Journal of Educational Technology, 48(2), 653671. https://doi.org/10.1111/bjet.12424

Żechowicz, M., Gromadziński, L., Dudziński, L., Grabarczyk, Ł., Żechowicz, T., Zabłocki, M., \& Zaborowski, P. (2018). Development and implementation of methods for training doctors and dental surgeons using virtual devices and simulation. Polish Annals of Medicine. https:/ / doi.org/10.29089/2017.17.00002 